\title{
ON SUPER EDGE-ANTIMAGICNESS OF SUBDIVIDED STARS
}

\author{
A. RAHEEM ${ }^{1}$ \\ Department of Mathematics \\ COMSATS Institute of Information Technology \\ Islamabad Campus, Pakistan \\ e-mail: rahimciit7@gmail.com \\ M. JAVAID ${ }^{2}$ \\ School of Mathematical Sciences \\ University of Science and Technology of China \\ Hefei, Anhui, P.R.China 230026 \\ e-mail: javaidmath@gmail.com. \\ AND \\ A.Q. BAIG \\ Department of Mathematics \\ COMSATS Institute of Information Technology \\ Attock Campus, Pakistan \\ e-mail: aqbaig1@gmail.com
}

\begin{abstract}
Enomoto, Llado, Nakamigawa and Ringel (1998) defined the concept of a super $(a, 0)$-edge-antimagic total labeling and proposed the conjecture that every tree is a super $(a, 0)$-edge-antimagic total graph. In the support of this conjecture, the present paper deals with different results on super $(a, d)$-edge-antimagic total labeling of subdivided stars for $d \in\{0,1,2,3\}$.
\end{abstract}

Keywords: super $(a, d)$-EAT labeling, stars, subdivision of stars.

2010 Mathematics Subject Classification: 05C78.

\footnotetext{
${ }^{1}$ Supported by COMSATS Institute of Information Technology, Islamabad, Pakistan.

${ }^{2}$ Supported by Chinese Academy of Science President's International Fellowship Initiative (CAS-PIFI), Beijing, China. Grant No: 2015 PM 035.
} 


\section{REFERENCES}

[1] M. Bača, Y. Lin, M. Miller and M.Z. Youssef, Edge-antimagic graphs, Discrete Math. 307 (2007) 1232-1244. doi:10.1016/j.disc.2005.10.038

[2] M. Bača, Y. Lin, M. Miller and R. Simanjuntak, New constructions of magic and antimagic graph labelings, Util. Math. 60 (2001) 229-239.

[3] M. Bača, Y. Lin and F.A. Muntaner-Batle, Super edge-antimagic labelings of the path-like trees, Util. Math. 73 (2007) 117-128.

[4] M. Bača and M. Miller, Super Edge-Antimagic Graphs (Brown Walker Press, Boca Raton, Florida USA, 2008).

[5] M. Bača, A. Semaničová-Feňovčíková and M.K. Shafiq, A method to generate large classes of edge-antimagic trees, Util. Math. 86 (2011) 33-43.

[6] Dafik, M. Miller, J. Ryan and M. Bača, On super $(a, d)$-edge antimagic total labeling of disconnected graphs, Discrete Math. 309 (2009) 4909-4915. doi:10.1016/j.disc.2008.04.031

[7] H. Enomoto, A.S. Lladó, T. Nakamigawa and G. Ringel, Super edge-magic graphs, SUT J. Math. 34 (1998) 105-109.

[8] R.M. Figueroa-Centeno, R. Ichishima and F.A. Muntaner-Batle, The place of super edge-magic labelings among other classes of labelings, Discrete Math. 231 (2001) 153-168. doi:0.1016/S0012-365X(00)00314-9

[9] R.M. Figueroa-Centeno, R. Ichishima and F.A. Muntaner-Batle, On super edgemagic graph, Ars Combin. 64 (2002) 81-95.

[10] Y. Fukuchi, A recursive theorem for super edge-magic labeling of trees, SUT J. Math. 36 (2000) 279-285.

[11] J.A. Gallian, A dynamic survey of graph labeling, Electron. J. Combin. 17 (2010).

[12] M. Javaid, M. Hussain, K. Ali and K.H. Dar, Super edge-magic total labeling on w-trees, Util. Math. 86 (2011) 183-191.

[13] M. Javaid, A.A. Bhatti and M. Hussain, On $(a, d)$-edge-antimagic total labeling of extended w-trees, Util. Math. 87 (2012) 293-303.

[14] M. Javaid, A.A. Bhatti, M. Hussain and K. Ali, Super edge-magic total labeling on forest of extended $w$-trees, Util. Math. 91 (2013) 155-162.

[15] M. Javaid, M. Hussain, K. Ali and H. Shaker, On super edge-magic total labeling on subdivision of trees, Util. Math. 89 (2012) 169-177.

[16] M. Javaid and A.A. Bhatti, On super $(a, d)$-edge-antimagic total labeling of subdivided stars, Ars Combin. 105 (2012) 503-512.

[17] M. Javaid, On super edge-antimagic total labeling of subdivided stars, Discuss. Math. Graph Theory 34 (2014) 691-705.

doi:10.7151/dmgt.1764 
[18] M. Javaid and A.A. Bhatti, Super $(a, d)$-edge-antimagic total labeling of subdivided stars and w-trees, Util. Math., to appear.

[19] A. Kotzig and A. Rosa, Magic valuations of finite graphs, Canad. Math. Bull. 13 (1970) 451-461. doi:10.4153/CMB-1970-084-1

[20] A. Kotzig and A. Rosa, Magic valuation of complete graphs, Centre de Recherches Mathematiques, Universite de Montreal (1972) CRM-175.

[21] S.M. Lee and Q.X. Shah, All trees with at most 17 vertices are super edge-magic, 16th MCCCC Conference, Carbondale (Southern Illinois University, November 2002).

[22] S.M. Lee and M.C. Kong, On super edge-magic $n$ stars, J. Combin. Math. Combin. Comput. 42 (2002) 81-96.

[23] Y.-J. Lu, A proof of three-path trees $P(m, n, t)$ being edge-magic, College Math. $\mathbf{1 7 ( 2 )}(2001)$ 41-44.

[24] Y.-J. Lu, A proof of three-path trees $P(m, n, t)$ being edge-magic (II), College Math. 20(3) (2004) 51-53.

[25] A.A.G. Ngurah, R. Simanjuntak and E.T. Baskoro, On (super) edge-magic total labeling of subdivision of $K_{1,3}$, SUT J. Math. 43 (2007) 127-136.

[26] A.N.M. Salman, A.A.G. Ngurah and N. Izzati, On super edge-magic total labeling of a subdivision of a star $S_{n}$, Util. Math. 81 (2010) 275-284.

[27] R. Simanjuntak, F. Bertault and M. Miller, Two new $(a, d)$-antimagic graph labelings, in: Proc. of Eleventh Australasian Workshop on Combinatorial Algorithms 11 (2000) 179-189.

[28] Slamin, M. Bača, Y. Lin, M. Miller and R. Simanjuntak, Edge-magic total labelings of wheel, fans and friendship graphs, Bull. Inst. Combin. Appl. 35 (2002) 89-98.

[29] K.A. Sugeng, M. Miller, Slamin and M. Bača, $(a, d)$-edge-antimagic total labelings of caterpillars, Lect. Notes Comput. Sci. 3330 (2005) 169-180.

[30] D.B. West, An Introduction to Graph Theory (Prentice-Hall, 1996).

Received 22 February 2014

Revised 12 February 2015

Accepted 12 February 2015 